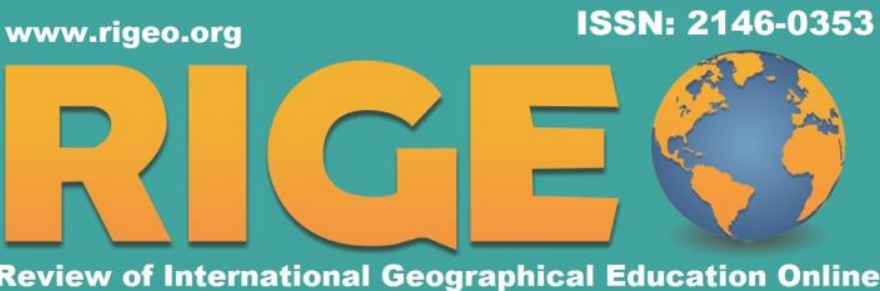

Review of International Geographical Education Online

(c) RIGEO Volume 8, Number 3, Winter 2018

Research Article

Copyright @ $\odot$ RIGEO 2018

To cite this article: Akkaya Yılmaz, M.; Karakuş, U. (2018). The Impact of Place Based Education Approach on Student Achievement in Social Studies. Review of International Geographical Education Online (RIGEO), 8(3), 500-516. Retrieved from http://www.rigeo.org/vol8no3/Number3winter/RIGEO-V8-N3-5.pdf

Submitted: May 15, 2018

Revised: November 27, 2018

Accepted: December 9, 2018

\title{
The Impact of Place Based Education Approach on Student Achievement in Social Studies*
}

\author{
Mavi AKKAYA YILMAZ ${ }^{1}$ \\ Adnan Menderes University, Aydın, TURKEY \\ Ufuk KARAKUŞ2 \\ Gazi University, Ankara, TURKEY
}

\begin{abstract}
The objective of this research is to examine the effectiveness of teaching the 6th grade (12-13 years old) social studies lessons' unit "Our Country's Resources" by place based teaching method on student achievement. This research was conducted in 2013-2014 academic year for six weeks in a public secondary school in Milas. In this research, an intervention and a control group were used. The intervention group was taught the unit with the place-based teaching method. The control group was taught the unit by their normal classroom instruction. Both the control and the intervention group student achievement was measured with pre- and post-tests, which were developed by the researcher, in order to examine the student achievement between the two groups. Post and pre-test scores was analysed by using Two-factor ANOVA. According to this analyse findings, the students of the experiment group educated with place based method attained the learning goals significantly higher as compared to the control group students receiving normal classroom instruction. In conclusion it is clear that place based education method more effective for student achievement in social studies education.
\end{abstract}

\section{Keywords}

Social Studies; Student Achievement; Place Based Education

Places are localities that can be explained meaningfully by the human experiences that take place in them. The sense of place reflects a set of meanings of and attachment

\footnotetext{
"This paper is based on the Ph.D dissertation presented in Gazi University, Institute of Educational Sciences, and Department of Social Studies Teaching.

${ }^{1}$ Corresponding author Assist. Prof. Dr., Aydın Adnan Menderes University, Faculty of Education, Department of Social Studies Education, Main Campus Kepez 09010 Aytepe, Aydın, Turkey, E-mail: mavi.akkaya [at] adu.edu.tr

${ }^{2}$ Assoc. Prof. Dr., Gazi University, Faculty of Education, Department of Social Studies Education, Beşevler 06500 Ankara, Turkey, E-mail: ukarakus [at] gazi.edu.tr
} 
to places assigned by individuals or groups (Semken, 2005, p. 149). Personal experiences in a place have a significant impact on the sense of place. Moreover, the level of individuals' sense of their local environment could affect their recognition of other environments. Educational activities play an important role in the recognition of the local environment and sense of place. Therefore, teachers should be the creators of the curriculum instead of being the implementers of curricula developed by others. They should be able to establish connections between students' performance standards determined by region or district and the unpredictable events that could occur outside the classroom. Teachers and group members should neglect the hypothesis which premises that suitable education can only be conducted in classrooms (Smith, 2002, p. 593-594). By adopting the democratic education perspective, schools should promote the meaningful introduction of the place-building process to the students (the process that shapes what our place would be) (Gruenewald, 2003b, p. 627). This can be achieved through a place-based perspective. Place-based pedagogies are needed, since they can directly affect citizen education and also affect the welfare of the social and ecological places where individuals live (Gruenewald, 2003a, p. 4). This reinforces the necessity of examining place-based education.

Literature shows that place-based education is used in several fields of education for different purposes. According to Woodhouse and Knapp (2000), place-based education refers to community-focused schooling, ecological education, and bioregional education. Although place-based education is rooted in environmental education, this approach can be distinguished from conventional environmental education, because the pioneers of place-based education focused on both social and natural environments (Smith, 2007, p. 190). In fact, five thematic models were mentioned in place-based education; these included cultural studies, nature studies, real-world problem solving, internship and entrepreneurial opportunities, and induction into community processes (Smith, 2002: pp. 587-591). Thus, place-based education is an approach based on the natural environment; it is also considered a growing trend in the wide landscape of education reform (Resor, 2010, p. 185). The place-based education method is an interdisciplinary and experienced learning approach which uses the local environment and society (Kuwahara, 2010, p. iii). In other words, place-based education can be identified as an educational approach which uses the local environment for its education and learning context. The primary objective of place-based education is to encourage students to get interested in their local society and allow them to take action to build a better future for their community (Russel Ciardi, 2006, p. 71). Place-based education is grounded in resources, issues, and values of the local community and focuses on using local community as an integrating context for learning. By enhancing the growth of cooperation between schools and their communities, the place-based education method not only helps student boost their achievements but also improves the quality of the community's environmental, social, and economic welfare simultaneously (Powers, 2004, p. 17).

Although the concept of place is rooted in the discipline of geography, place-based projects are usually multidisciplinary and interdisciplinary (Sobel, cited by Resor, 2010, 
p. 185). Place-based education, which is utilised in language, arts, mathematics, social studies and, science education, improves students' perceptions about local heritage, culture, ecology, landscapes, opportunities, and experiences with them. It encourages teachers and students to use the schoolyard, society, public areas, and other special spaces as resources for turning communities into classrooms (PEEC, 2010). Moreover, this educational method effectively helps children overcome the disconnection between their lives and the school due to its ability to harmonise special features of particular places (Smith, 2002, p. 593). In short, place-based education helps students learn to care about the world by helping them understand the place they live in and take action on their own backyards and communities (PEEC, 2010).

Place-based education is multidisciplinary and gives importance to the acquisition of experience in students' local environments. Social studies education is also multidisciplinary, and includes topics from various disciplines. Therefore, place-based education shares several common features with the social studies course, and the use of this method could potentially contribute to the social studies field. The literature review revealed several studies on place-based education (Wahburn, 2003; Blaich, 2003; Way, 2005; Conaway, 2006; O'Connor, 2006; Reisberg, 2006; Duffin and Peer, 2006; Mansour, 2007; Cook, 2009; Glienert, 2009; Tatistcheff, 2009; Garrison, 2009; Rushmere, 2009; O’Connor, 2009; Azona, 2009; Cole, 2010; Kuwahara, 2010; Wu, 2010; Rosenthal, 2011; Tanzer, 2011; Morehouse, 2011; Weigand, 2011; Marshall, 2011; Köşker, 2011; Klechaya, 2012; Evans and Kılınç, 2013). However, only a few studies were conducted on place-based education in Turkey. Thus, studies on placebased education will contribute positively to social studies education and fill the gap regarding such studies in Turkey. The present study was planned as an experimental design. While many studies have investigated the effectiveness of the place-based teaching method, no research has thus far examined place-based teaching in a social studies education setting in Turkey.

The present study aims to examine the degree to which the place-based teaching method makes a difference in student achievement in social studies education. For this aim, the 6th grade (12-13 years old) social studies topic, "The Resources of Our Country", was taught within two groups of students, a control and an intervention group, in a public school in Milas, a district in Southern Turkey.

\section{Methodology}

\section{Research Model}

This research was conducted with an experimental design. Experimental designs aim to define the causality in the data that are observed within the researchers' control (Karasar, 2009, p. 87). In the present study, a pre-test/post-test control group design is used; this design is generally used in complex method studies (Büyüköztürk from Howit, 2007, p. 19). Under this design, two groups are randomly constituted; one of the groups is used as the intervention and the other is used as the control group. In both groups, measurements are gathered before and after the application (Karasar, 2009, p. 97). 


\section{Participants}

The study group included two groups of sixth-grade students of a Muğla/Milas state school in the 2013-2014 education term. One was designated as the intervention group, and the other is the control group. Place-based education focuses on a variety of unique features within a place. The researcher, who was born and raised in Milas, is very familiar with the characteristics of the area. Furthermore, it was observed that Milas offers a very suitable climate for field trips during February and March, and therefore, the research was conducted during this period. During the selection of the school, all secondary schools in Milas were listed, and a school was randomly selected. Then, consent was obtained from the Muğla Provincial National Education Directorate to conduct the research for the selected school. The cluster sampling method was used to determine the grade of students to be examined in the present study. This method is used when there are naturally or artificially created groups that demonstrate definite similarities with regard to a subject under study (Yıldırım and Şimşek, 2011, p. 105). The groups were determined wholly and randomly. As a result, the 6-B class was assigned as the intervention group, and the 6-A class was assigned as the study group. Field expert opinions were obtained about conducting the study with an intervention and a control group. It was decided that the study should be conducted with only one intervention and one control group due to the challenges of conducting several applications outside of school and the schoolyard. Furthermore, since the participating students were 12-13 years old, parental consent letters were obtained regarding the students' participation. Before initiating the experimental study, the researcher met separately with both groups and provided detailed information about it. Both groups were instructed by the researcher, and the external factors were controlled as much as possible to ensure the reliability of the research. Distribution of the participants in the groups and certain demographics are provided below:

Table 1

The Study Participants

\begin{tabular}{lccc}
\hline Group & Public school & Total \\
\hline Intervention (6-B) & 26 & & 26 \\
Control (6-A) & & 27 & \\
Total & 26 & 27 & 53 \\
& & & \\
\hline
\end{tabular}


Table 2

Participant Demographics

\begin{tabular}{|c|c|c|c|c|}
\hline & \multicolumn{2}{|c|}{ Intervention Group } & \multicolumn{2}{|c|}{ Control Group } \\
\hline & $\mathrm{f}$ & $\%$ & $\mathrm{f}$ & $\%$ \\
\hline \multicolumn{5}{|l|}{ Gender } \\
\hline Female & 13 & 50 & 11 & 40.7 \\
\hline Male & 13 & 50 & 16 & 59.3 \\
\hline Total & 26 & 100 & 27 & 100 \\
\hline \multicolumn{5}{|c|}{ Mother's Educational Status } \\
\hline Primary School & 16 & 61.5 & 17 & 63.0 \\
\hline Junior High School & 5 & 19.2 & 6 & 22.2 \\
\hline High School & 4 & 15.4 & 4 & 14.8 \\
\hline College & 1 & 3.8 & - & - \\
\hline Total & 26 & 100 & 27 & 100 \\
\hline \multicolumn{5}{|c|}{ Father's Educational Status } \\
\hline Primary School & 8 & 30.8 & 9 & 33.3 \\
\hline Junior High School & 5 & 19.2 & 9 & 33.3 \\
\hline High School & 9 & 34.6 & 7 & 25.9 \\
\hline College & 4 & 15.4 & 2 & 7.4 \\
\hline Total & 26 & 100 & 27 & 100 \\
\hline \multicolumn{5}{|l|}{ Mother's Occupation } \\
\hline Homemaker & 20 & 76.9 & 16 & 59.3 \\
\hline Public Servant & 1 & 3.8 & 2 & 7.4 \\
\hline Self-Employed & 5 & 19.2 & 9 & 33.3 \\
\hline Total & 26 & 100 & 27 & 100 \\
\hline \multicolumn{5}{|l|}{ Father's Occupation } \\
\hline Public Servant & 10 & 38.5 & 6 & 22.2 \\
\hline Farmer & - & - & 1 & 3.7 \\
\hline Small Business Owner & 5 & 19.2 & 7 & 25.9 \\
\hline Self-Employed & 11 & 42.3 & 11 & 40.7 \\
\hline Retired & - & - & 2 & 7.4 \\
\hline Total & 26 & 100 & 27 & 100 \\
\hline \multicolumn{5}{|c|}{ Average Monthly Income } \\
\hline $501-1000 \mathrm{TL}$ & 6 & 23.1 & 4 & 14.8 \\
\hline $1001-1500 \mathrm{TL}$ & 6 & 23.1 & 5 & 18.5 \\
\hline $1501-2000 \mathrm{TL}$ & 3 & 11.5 & 8 & 29.6 \\
\hline 2000 TL and over & 11 & 42.3 & 10 & 37.0 \\
\hline Total & 26 & 100 & 27 & 100 \\
\hline
\end{tabular}

The Application Process

This study was conducted in the 2013-2014 academic year with 6th grade students in the social studies course, "Our Country's Resources." In this scope, the application included nineteen activities in class and thirteen out of class, with a total of thirty-two activities conducted over the course of six weeks. The intervention group courses were instructed using the place-based instructional approach, while the control group courses 
were instructed based on the curriculum. While courses were conducted in the intervention group, fourteen study sheets were prepared with respect to the topics in the unit and the prepared lesson plans for this framework. These study sheets were provided for students during the instruction of the course.

All activities in the lesson plan were prepared by the researcher. However, the benefits of certain activities were based on those cited in the international literature. These activities were adapted to Milas. Eight classroom activities conducted during the first week were developed and prepared by the researcher. Four in-classroom activities were conducted using the previously designed study sheets. Four out-of-classroom activities were conducted in nearby locations. During the out-of-classroom activities planned for the first week, certain statements mentioned in a study by Smith (2002) attracted the attention of the researcher. Smith mentioned that his students were growing local plant species, and Smith expressed that the students provided meal services regularly to the homeless and low-income individuals in Blanchet House. Thus, the researcher prepared an activity that included growing local plants in Milas. During the winter months, broad bean, sour dock (local name ekşimen), lettuce, spinach, and peas (all of which grow in the region) were planted, and the students recorded their observations every week in their study sheets to improve their observational abilities. The plants the group would grow were designated with the numbers 1 to 5 , as chosen by the students. Furthermore, an attempt was made to improve the students' social awareness. In this framework, the students' parents were involved, and they were asked about people with financial problems living in their neighbourhood. At the end of the study, the cultivated crops were provided to these families. While designing the second out-of-classroom activity for the first week, a study by Garrison (2009) was utilized. For this activity, the researcher brought a pot filled with soil to the open activity area. The researcher blew over the pot to imitate the effect of the wind by positioning herself at the center of the students who sat in a circle. Then, the researcher irrigated the pot with an injector filled with water to replicate the rain effect. Then she asked the students what she was trying to explain, with the aim of encouraging them to deduct the definition of erosion via observation and thought. The third out-of-classroom activity in the first week was planned by the researcher. In this activity, students were taken to a field, where they participated in an olive harvest after the required authorization was obtained from the authorities. The fourth out-of-classroom activity for the first week utilized the design by Conaway (2006). The researcher adapted this activity to the local setting. The researcher considered again that the olive harvest activity was adequate for the vicinity of Milas and designed the work sheets for this specific region; for this activity, the students were asked to write the names of three plants. Moreover, similar to Tanzer's (2011) study, a group of students collected insects and confirmed which ones they had already known and which they had learned for the first time. The researcher ensured that the students had noted all insect types they saw on the worksheets.

In the second week, four in-classroom activities and two out-of-classroom activities were performed, for a total of six activities. In this context, the work sheets were used for each related topic, and the lesson was designed using question-answer and 
discussion methods and techniques. For an out-of-classroom activity, an observation trip was organized to Balavca River in Milas. The students were asked to note their observations about problem situations they observed near the river on their worksheets. Then, the students set hypotheses for the problems on their worksheets, conducted research, tested the hypotheses, and created solutions. Finally, the problems and the suggestions determined by the students were reported to the local municipality of Milas. In another out-of-classroom activity, an oral history study was made with elderly local people about the history of the thermal power and coal mining plants which were located in Milas.

In the third week, six out-of-classroom activities were done. For the first activity, students were taken to a forest in central Milas and were given information about forests. The second activity was based on a study by Findeisen (2011), in which students were divided into two groups that included two students each. Within each group, one student was asked to close his or her eyes, and the other student was asked to choose a tree for him or herself. The student who could see took his or her peer close to the tree and described the tree in detail. Then, the two returned back to their original location and the second student was allowed to open his or her eyes. The student who had described the tree asked his/her peer to find the tree in question. In the third activity, the students were instructed regarding forests and their benefits. In the fourth activity, the students were divided into groups and asked to find problems related to the forest and suggest solutions. In this activity, the process involved a discussion on the students' comments, and the steps mentioned on the worksheets were completed. The obtained solution recommendations were finally presented on the school bulletin board to inform the other students as well. In the fifth activity, a story written by the researcher was read with the students, and they were asked to explain the story concepts. In the sixth activity, the students were taken to an olive oil factory to obtain information about the factory and its operations. The students then were asked to consider themselves as an owner of such as an olive factory, aqua culture corporation, food-catering business, or mining or wood products company. They were then asked to present ways to improve the trade volume and profitability of these businesses based on the instructions included in their worksheets.

During the fourth week, two in-classroom activities and one out-of-classroom activity, for a total of three activities, were prepared. In the first in-classroom activity, a mind map about the tax concept was created. Then, in the second activity, the opinion development technique was applied regarding the tax concept. One out-of-classroom activity was inspired by a study by Smith (2002). The class discussed the topic of taxes and their benefits to the public such as funding for parks and listed the problems experienced in the district parks. Observations were made regarding problems in certain parks. The problems and the needs determined were later reported to the local municipality of Milas.

In the fifth week, five in-classroom activities were done. The topics covered in the fifth week were initially discussed using certain visual materials on the scarcity of 
natural resources, and the students completed short stories which had already been on their worksheets.

In the sixth week, four in-classroom activities were done. The activities were conducted upon asking the students to write examples for manufacturing, service, and agricultural industry jobs on the prepared worksheets. The information provided about these jobs was discussed through the question-answer technique in class. Here some pictures are presented from the application process.

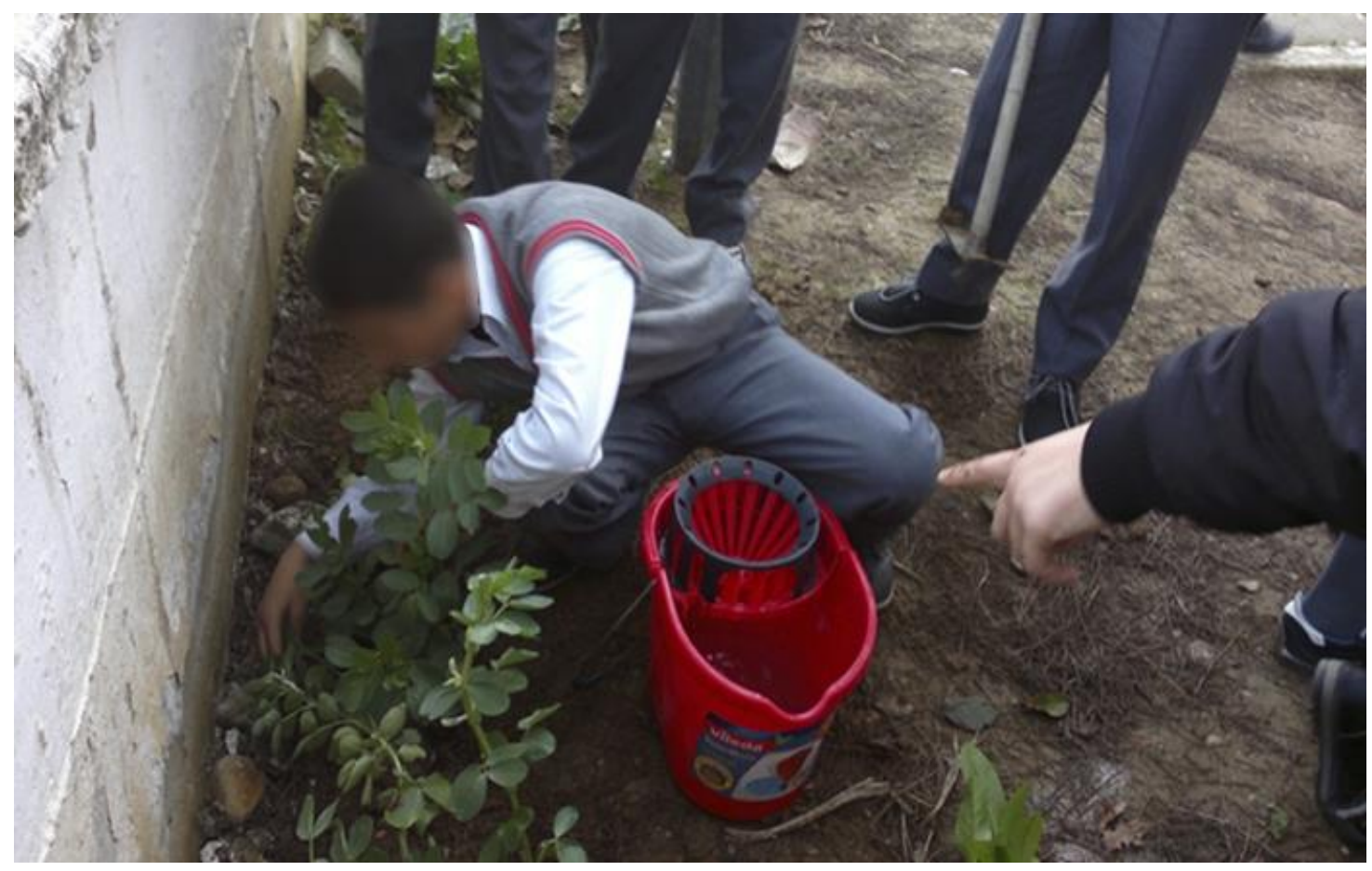

Figure 1. First week of the application 


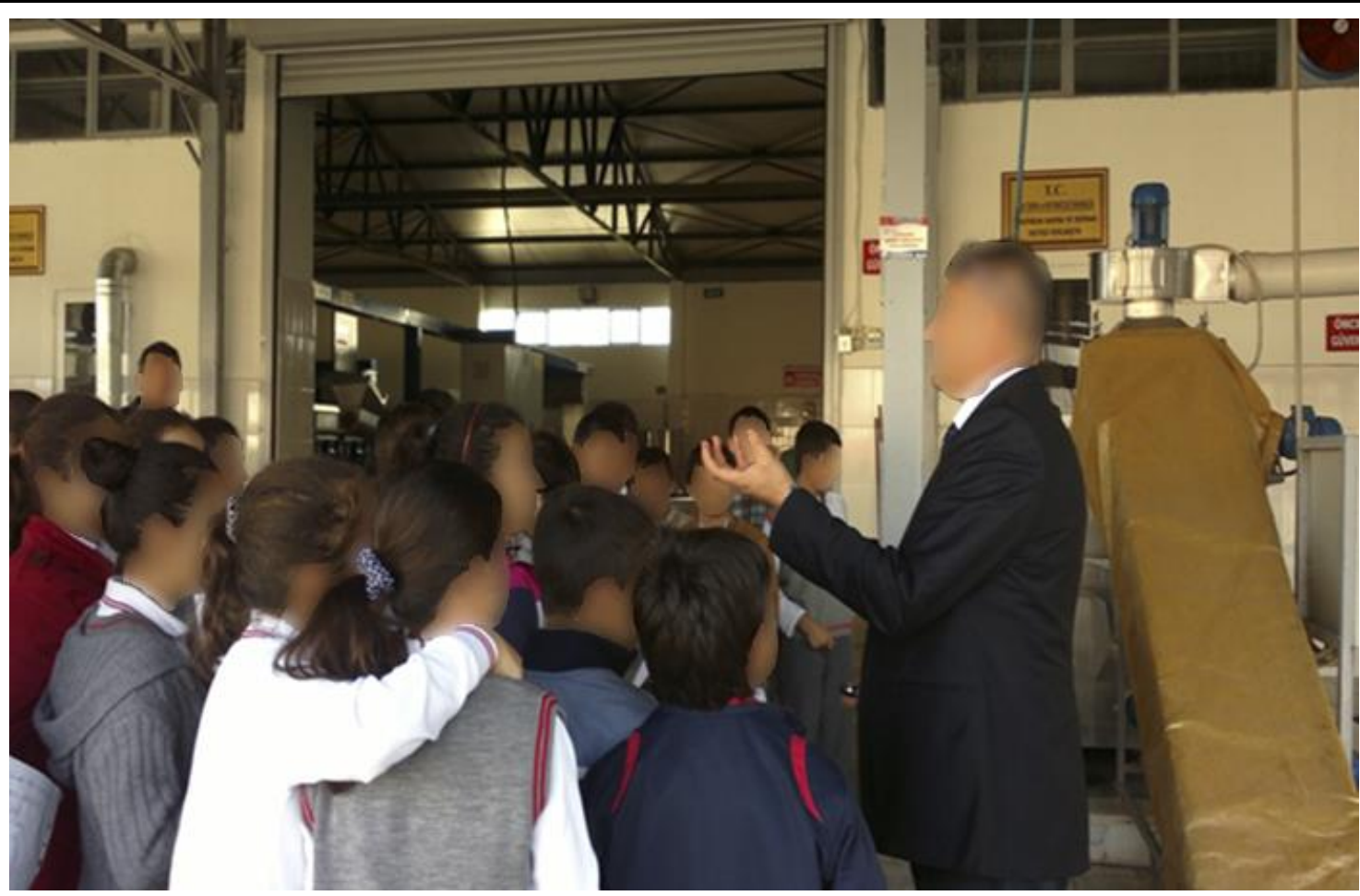

Figure 2. Third week of the application

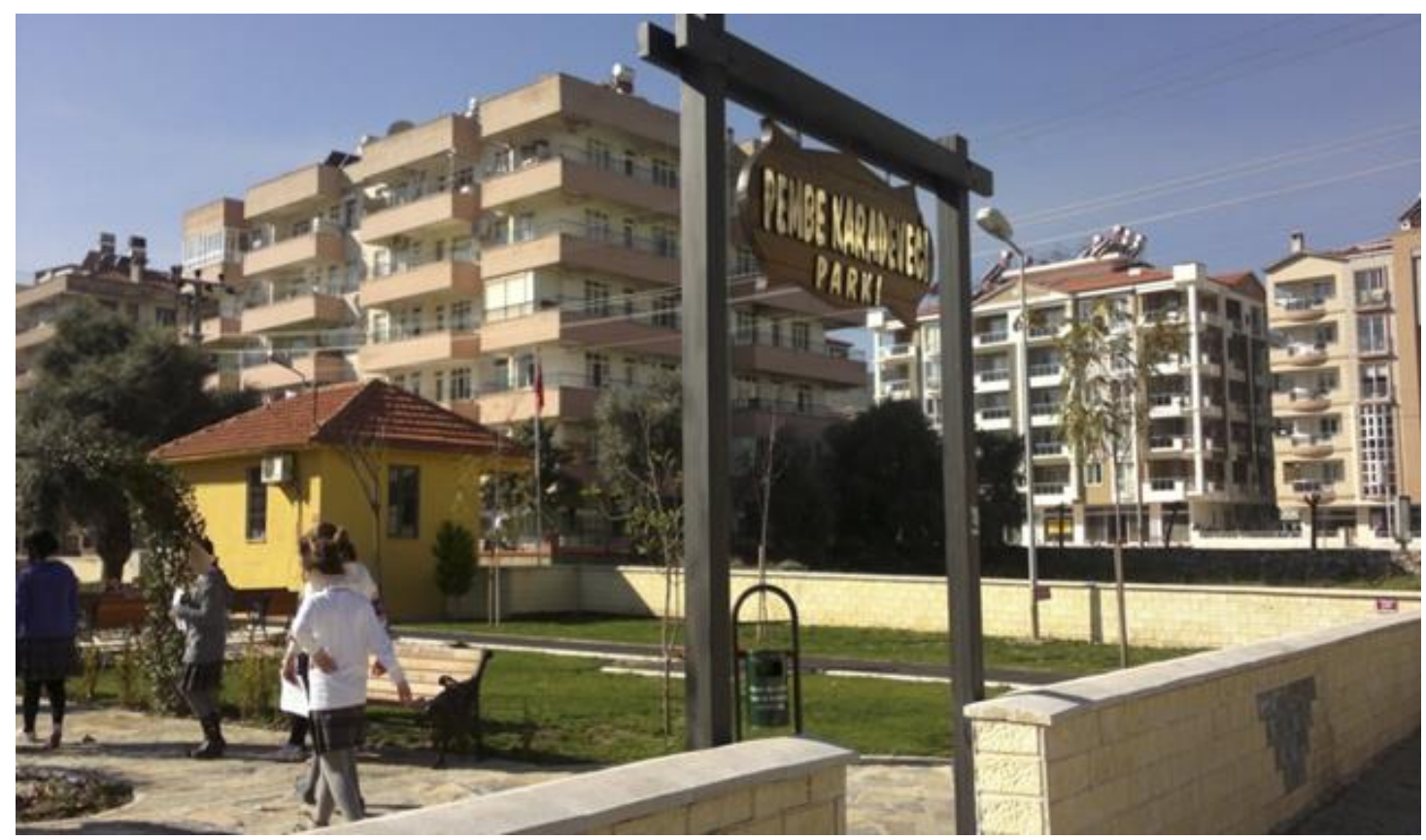

Figure 3. Fourth week of the application

\section{Data Collection Instrument}


In the study, an achievement test, which constituted of 50 questions, was prepared about the unit, "The Resources of Our Country," for 6th grade students. Three academic staffs of Social Studies Education and two academic staffs of Turkish Education were asked about the questionnaire for an expert opinion. The 2nd, 13th, 15th, 17th, 19th, 27th, 28th, and 30th questions were edited, and the 37th question was excluded from the questionnaire in response to the expert opinion. A pilot execution was conducted with 150 students attending 7-C, 7-I, 7-H, 7-K, and 7-L classes in Ankara Ilisu Sincan District Ahmet Andiçen Junior High School. An item analysis of the questionnaire was conducted in this study. When analyzing the items, the researcher considered item difficulty and the index of item differentiation.

On the achievement test twelve questions were excluded which did not have adequate differentiation index values. In general, it was stated that items that explained .30 or more of the total variance differentiated the individuals well, and items that explained between .20 and .30 of the total variance should be tested if deemed necessary and should be edited (Büyüköztürk, 2012, 171). Accordingly, items 2, 29, 41, and 43 were tested. Item 49 was removed, since it measured the same factor with items 46, 47, and 48, although it had adequate difficulty and differentiation loads. Also, item 13 was not included in the test. Based on the age level and the distribution of the questions based on the topics, the numbers of twenty five questions were included in the test, and each was a multiple-choice question with four response options. Bademci (2011) stated that the Cronbach's alpha coefficient could be used with items measured with both binary $(0,1)$ and Likert-type $(1,2,3,4,5)$ systems (p. 173). Accordingly, it was determined that the Cronbach's alpha reliability coefficient was 0.814 for the achievement scale.

\section{Data Analysis}

The data was collected by using the achievement test applied as both pre-test and post-test to the intervention and control groups. Collected data were analysed with SPSS 18.0 software. Data analysis was conducted with two-factor ANOVA (repeated measures).

\section{Findings}

In the analysis, the differences between the scores of the intervention and control group students on the achievement test in the social studies course unit, "Our Country's Resources," were analysed based on the groups (intervention-control), measurements (pre-test/post-test), and common effect. The analysis results are presented in Table 4.

The pre-test and post-test mean scores of the students in "Our Country's Resources" unit achievement test and standard deviation figures are presented in Table 3. 
Akkaya Yılmaz, M., Karakuş, U. (2018). The impact of place based education approach on student....

Table 3

The Pre-Test and Post-Test Mean Achievement Scores of the Students in the Unit "Our Country's Resources" And Standard Deviation Values.

\begin{tabular}{lcccccc}
\hline Group & \multicolumn{3}{c}{ Pre-test } & \multicolumn{3}{c}{ Post-test } \\
\hline & $\mathrm{N}$ & $\overline{\mathrm{X}}$ & $\mathrm{S}$ & $\mathrm{N}$ & $\overline{\mathrm{X}}$ & $\mathrm{S}$ \\
Intervention & 26 & 11.69 & 3.86 & 26 & 19.42 & 4.86 \\
Control & 27 & 10.59 & 3.31 & 27 & 14.33 & 4.10 \\
\hline
\end{tabular}

As seen in the second table, the pre-test mean achievement score of the intervention group students, who were instructed with place-based instruction in the unit, "Our Country's Resources," was $\bar{X}=11.69$; however, their post-test mean achievement score was $\bar{X}=19.42$. The pre-test mean achievement score of the control group students, who were instructed based on the curriculum, was $\bar{X}=10.59$ and their post-test score was $\bar{X}$ $=14.33$. Thus, it can be stated that the mean scores of both student groups improved after the instruction of the unit "Our Country's Resources" using both methods.

The variance between the intervention group students' pre-test and post-test scores in the "Our Country's Resources" unit was analysed using two-factor ANOVA (repeated measures) and presented in Table 4.

Table 4

The Result of the ANOVA Test Conducted On "Our Country's Resources" Unit Achievement Scores.

\begin{tabular}{lccccc}
\hline Source of Variance & $\begin{array}{c}\text { Sum of } \\
\text { Squares }\end{array}$ & df & $\begin{array}{c}\text { Mean } \\
\text { Square }\end{array}$ & F & P \\
\hline Between-groups & 1133.962 & 52 & & & \\
Group (I/C) & 253.709 & 1 & 253.709 & 14.699 & .000 \\
Error & 880.253 & 51 & 17.260 & & \\
Within-groups & 1783.095 & 53 & & & \\
Measurement (Pre-test-Post-test) & 871.510 & 1 & 871.510 & 55.135 & .000 \\
Group* Measurement & 105.435 & 1 & 105.435 & 6.670 & .013 \\
Error & 806.150 & 51 & 15.807 & & \\
Total & 2917.057 & 105 & & & \\
\hline
\end{tabular}

There was a significant difference between the pre-test and post-test unit achievement scores for "Our Country's Resources" among the intervention and control group students $\left[\mathbf{F}_{(1-51)}=14,699 ; \mathbf{p}<\mathbf{0 . 0 5}\right.$. This finding demonstrated that the unit achievement scores of the intervention and control group students differed independent of the measurement (pre-test and post-test).

There was a significant difference between the mean pre-test and post-test unit achievement scores for "Our Country's Resources" among the intervention and control group students $\left[\mathbf{F}_{(1-51)}=55.135 ; \mathbf{p}<\mathbf{0 . 0 5}\right]$. These findings suggested that "Our Country's Resources" unit achievement scores of the students differed based on the instruction model. 
Based on the analysis results presented in Graph 3, there was a significant difference between the pre-test and post-test unit achievement scores for "Our Country's Resources" among the students based on the intervention and control group. In other words, the common effects of the different application groups (intervention and control group) and repeated measurements were significant on the unit achievement test scores $\left[\mathbf{F}_{(1-51)}=6,670 ; \mathbf{p}<\mathbf{0 . 0 5}\right]$. This finding demonstrated that place-based and curriculumbased instruction had different effects on improving student achievement in the unit "Our Country's Resources." There was a difference between the unit achievement scores of the students based on the tests. In other words, the achievements of the students in the "Our Country's Resources" unit varied based on the empirical process. Thus, it is suggested that this was due to the application of the place-based teaching method. It was demonstrated that place-based teaching helped improve the students' achievement in the unit "Our Country's Resources" more significantly when compared to the curriculum-based instruction. The comparison of students' pre-test and post-test achievement scores is presented in Graph 1.

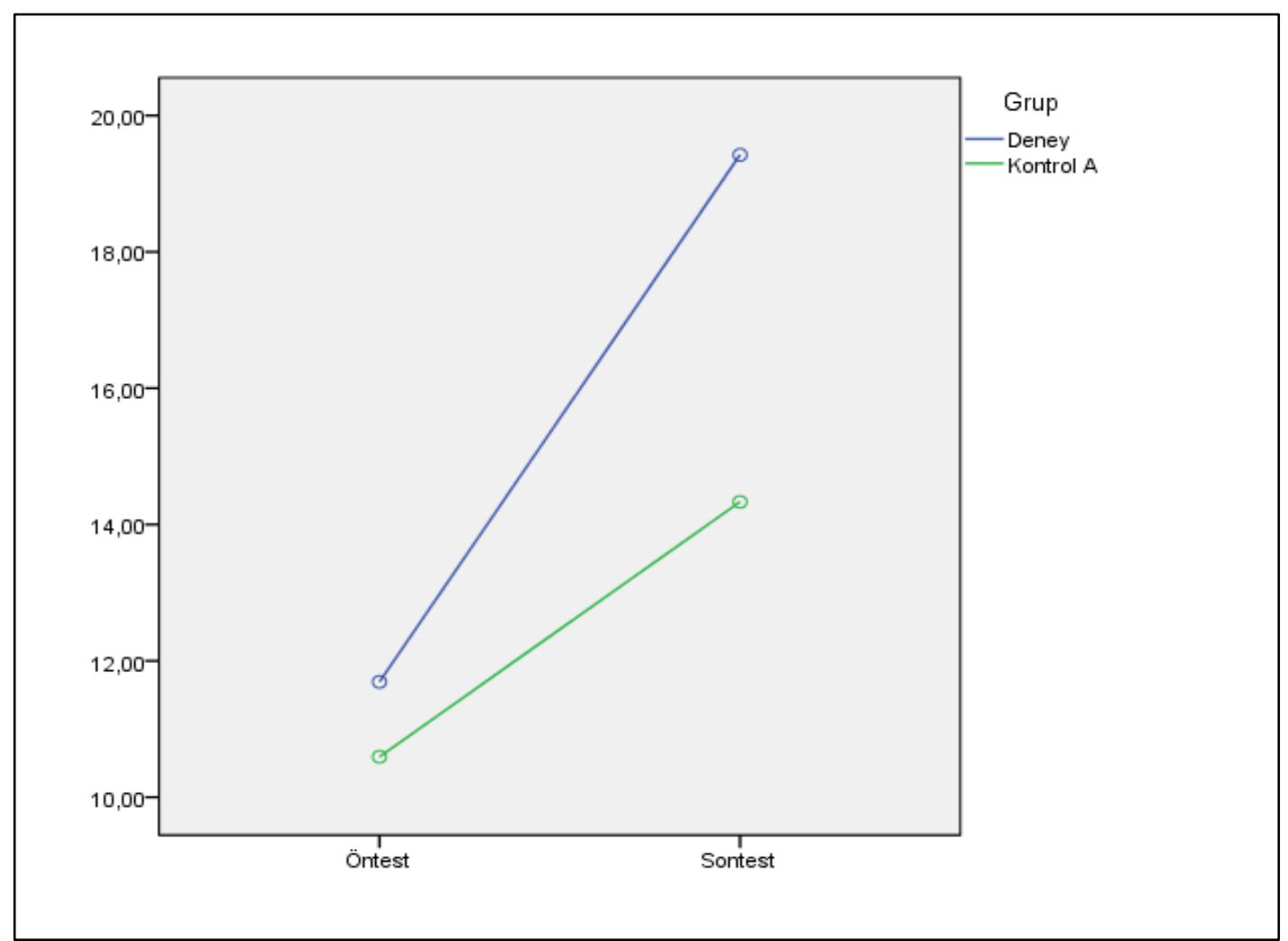

Graph 1. Pre-test and post-test achievement scores of intervention and control group students in the "Our Country's Resources" unit.

\section{Conclusion and Discussion}

Study findings demonstrated that the achievements of both groups improved. However, the achievement scores of the intervention group differed significantly when compared to those of the control group. In other words, the intervention group receiving 
instruction through the place-based teaching method attained the learning goals significantly more effectively than the control group students who received normal classroom instruction. This indicated that the instruction of the course with the placebased teaching method had a higher impact on the achievement of the students in the intervention group. Evans and Kılınç (2013) indicated that place-based education improves the achievements in all courses, especially in social studies courses. Metzger (2013) conducted a study on 11-14-year-old students attending state schools in California. Qualitative methods and place-based education were utilized in the study. Study findings demonstrated that the outdoor environment improved the students' learning motivation. In the present study, outdoor activities were conducted with the intervention group. It was observed that the students exhibited great interest in these activities, and student achievement improved as a result.

A study by Blaich (2003) indicated that the place-based Hawaiian curriculum had a positive impact on both Hawaiian and non-Hawaiian students. Blaich determined that the concentration, learning, and retention of the students instructed outdoors were better when compared to that of the students instructed in the classroom. Way (2005) utilized the place-based teaching method and found that participants acquired meaningful learning on the research topic through place-based education. In another study, Cornell (2007) conducted an experimental study with adults using environmental education, which is closely related to place-based education. The study findings demonstrated that the environmental content of the intervention group was significantly different. In the present study, the students emphasized that they learned the material in the unit "Our Country's Resources" better with the place-based teaching method. Mansour (2007) conducted a study using the place-based education program in rural and urban junior high schools in Lebanon. The study findings demonstrated that the program had a positive impact on students' learning attitudes and behaviour. As a result of the action plan implemented in a study by Cook (2009), it was demonstrated that the students' knowledge, awareness, and value they assigned to the local environment improved. Marshall (2011) applied the place-based curriculum in the instruction of the topic of snow. The study findings demonstrated that the acquisition of in-depth knowledge through experience could significantly affect individuals' perceptions about the place in which they lived and their self-perceptions. In the present work, students also learned about the local environment in the "Our Country's Resources" unit (natural resources and lands, waters and mines, etc.). Students had several experiences within the local environment during the study. As a result, students' curiosity, interest, and knowledge about the local environment improved, and it can be suggested that this research also had an impact on their learning and achievements.

\section{Recommendations}

In conclusion, it was determined that the place-based teaching activities improved the achievement of students. Thus, such an approach would be beneficial to the instruction of other units in social studies and in other subjects within the Turkish National Education. It is suggested that teachers be trained in this area, as the placebased instruction activities would be conducted in the areas where the schools are 
located. Furthermore, local facilities should be considered, and the activities should be planned accordingly when the activities are developed. Pre-testing the activities developed by the teachers could also improve place-based education.

There are two main difficulties that challenge the application of the place-based teaching method. The first relates to the difficulties that arise when taking students outdoors, and the second involves the limitations related to course duration. It would be very difficult to take the students out of school during classes; therefore, all adequate leave permits should be established in advance. Schools should also take into consideration the distance to the activity location in advance. During the application process of this research, the students stated that they enjoyed the activities and effectively learned about their environment. Thus, the students' sense of belonging to the local environment could be investigated for experimental studies in the future.

\section{References}

Azano, A.P. (2009). The Possibility of place: one teacher's use of place-based instruction for English students in a rural high school (Unpublished Doctoral Dissertation). University of Virginia, Charlottesville.

Bademci, V. (2011). Kuder-richardson 20, cronbach'ın alfası, hoyt'un varyans analizi, genellenebilirlik kuramı ve ölçüm güvenirliği üzerine bir çalışma. Dicle Üniversitesi Ziya Gökalp Eğitim Fakültesi Dergisi, 17, 173-193.

Blaich, M. D. B. (2003). Mai uka a i kai: from the mountains to the sea 'aina-based education in the ahupua'a of waipa (Unpublished Master's Thesis). The University of Hawai'i, Manoa.

Büyüköztürk, Ş. (2007). Deneysel desenler öntest-sontest kontrol grubu desen ve veri analizi. Ankara: Pegem A Yayıncilı.

Cole, A.G. (2010). Adolescent geographies in the clasroom: Interactions with place- and community-based education (Unpublished Doctoral Dissertation). University of New Mexico Albuquerque, New Mexico.

Conaway, J.D. (2006). Mississippi river program: A mixed-method examination of the effects of a place-based curriculum on the environmental knowledge and awareness of Montessori adolescents (Unpublished Master's Thesis). Minnesota State University, Mankato.

Cook, L. (2009). Developing a sense of place: examining educator practice in place-based education, (Unpublished Master's Thesis). Prescott College, Arizona.

Cornell, J.A. (2007). Creating environmental stewardship: evidence from a community-based adult education program (Unpublished Doctoral Dissertation). George Mason University, Fairfax,VA.

Duffin, M., and PEER Associates. (2006). Why use place-based education in your school? Four answers that emerge from the findings of PEEC, the Place-based Education Evaluation Collaborative. Retrieved from http://www.promiseofplace.org/index.php?id=64

Evans, R. T. ve K1lınç, E. (2013). History of place-based education in the social studies field. Adlyaman Üniversitesi Sosyal Bilimler Enstitüsü Dergisi, (14), 263-280. 
Findeisen, C. (2011). The hog island project: developing a place-based curriculum, unpublished master's thesis, Prescott College, Arizona.

Garrison, E.M. (2009). Developing a framework for sense of place education within elementary science instruction (Unpublished Master's Thesis). Prescott College, Arizona.

Glinert, A. (2009). Teaching placed-based environmental education to English language learners (Unpublished Master's Thesis). Prescott College, Arizona.

Gruenewald, D. (2003a). The best of both worlds: A critical pedagogy of place. Educational Researcher, 32(4), 3-12.

Gruenewald, D. (2003b). Foundations of place: A multidisciplinary framework for placeconscious education, American Educational Research Journal, 40(3), 619-654.

Karasar, N. (2009). Bilimsel araştırma yöntemi. Ankara: Nobel Yayın Dağıtım.

Klechaya, R. (2012). Place-based science education for five elemantary schools in rural Thailand, (Unpublished Doctoral Dissertation). University of Hawai' i, Manoa.

Köşker, N. (2011). Coğrafya eğitiminde yer temelli öğretim yaklaşımına ilişkin öğretmen görüşleri (Yayımlanmamış Doktora Tezi). Gazi Üniversitesi, Eğitim Bilimleri Enstitüsü, Ankara.

Kuwahara, J. L. H. (2010). Effectiveness of place-based science curriculum projects situated in Hawaiian and Western cultural institutions at an urban high school in Hawai'i (Unpublished Doctoral Dissertation). University of Hawai'i, Manoa.

Macinerney, P. , Smyth, J., and Down, B. (2011). Coming to a place near you?' The politics and possibilities of a critical pedagogy of place-based education, Asia-Pacific Journal of Teacher Education, 39(1). 3-16.

Mansour, S. (2007). Place-based learning environments: Lebanese secondary student perceptions of environmental experiences of learning (Unpublished Master's Thesis). University of British Columbia, Vancouver.

Marshall, C.C (2011). Achieving sense of place and self through snow (Unpublished Master's Thesis). Prescott College, Arizona.

Metzger, N. (2013). Educating for belonging: place-based education for middle school students (Unpublished Master's Thesis). Prescott College, Arizona.

Morehouse, A. (2011). Liquid edges of place \& pedagogy: sense of place and community-based youth engagement in The Dalles, or (Unpublished Doctoral Dissertation). Prescott College, Arizona.

O'Connor, K.B. (2006). Investigations into indigenous research and education through an experiential and place-based lens (Unpublished Master's Thesis). McGill University, Montreal.

O'Connor, K.B. (2009). Puzzles rather than answers: co-constructing a pedagogy of experiential, place-based and critical learning in indigenous education (Unpublished Doctoral Dissertation). McGill University, Montreal. 
PEEC (2010). The Benefits of Place-based Education: A Report from the Place-based Education Evaluation Collaborative (Second Edition). Retrieved from http://www.litzsinger.org/PEEC2010_web.pdf.

Powers, E.L. (2004). An evaluation of four place-based education programs. The Journal of Environmental Education. 35(4). 17-32.

Reisberg, M. (2006). An a/r/tographic srudy of multicultural children's book artists: developing a place- based pedagogy of pleasure (Unpublished Doctoral Dissertation) Washington State University, Pullman.

Rushmere, A. (2009). Fermenting the free folk school: tending a culture of place-based ecological learning and living (Unpublished Master's Thesis). Simon Fraser University, Burnaby.

Russel Ciardi. M. (2006). Place-based education in an urban environment. Museum International. 58(3). 71-77.

Semken, S. (2005). Sense of place and place-based introductory geoscience teaching for American Indian and Alaska Native undergraduates. Journal of Geoscience Education, 53(2), 149-157.

Smith, G.A. (2002). Place-based education learning to be where we are. Phi Delta Kappan, April, 584-594.

Smith, G.A. (2007). Place-based education: breaking through the constraining regularities of public school, Environmental Education Research, 13(2), 189-207.

Resor, C.W. (2010). Place-based education: What is its place in the social studies classroom?, The Social Studies, 101(5), 185-188.

Tanzer, E. (2011). Sense of place development: A teacher's action research project (Unpublished Master's Thesis). Prescott College, Arizona.

Tatistcheff, R. K. (2009). Divergent meanings of place: two instantiations of place-based curriculum in a rural school (Unpublished Doctoral Dissertation). Columbia University, New York.

Washburn, D.L. (2003). Teacher commitment to place-based education in rural southeastern Ohio appachian high schools (Unpublished Doctoral Dissertation). Ohio University, Athens.

Way, J.G. (2005). Assessing student learning and interest in eastern coyotes (Unpublished Doctoral Dissertation). Boston College, Chestnut Hill.

Weigand, R. (2011). A garden of learning: exploring critical place-based pedagogy in kindergarten (Unpublished Master's Thesis). University of Toronto, Toronto.

Woodhouse, J. L., ve Knapp, C. E. (2000). Place-based curriculum and instruction: outdoor and environmental education approaches. ERIC Digest.Charleston, WV: ERIC Clearinghouse for Rural Education and Small Schools.(ERIC Document Reproduction Services No. ED 448 012).

Wu, P. Z. (2010). Demarginalizing knowledge through place-based learning: exploring the eductional experience at the lo'i (Unpublished Master's Thesis). University of Hawai'i, Manoa. 
Yıldırım, A. ve Şimşek, H. (2011). Sosyal Bilimlerde Nitel Araştırma Yöntemleri. Ankara: Seçkin Yayıncılık.

\section{Biographical statements}

Mavi AKKAYA YILMAZ is an Assistant Professor in the Department of Turkish and Social Studies Education at the Aydın Adnan Menderes University in Turkey. Her research interests focus on entrepreneurship, culture and culturel heritage, communication skills and using place-based education method in social studies education.

Ufuk KARAKUŞ is an Associate Professor in the Department of Turkish and Social Studies Education at the Gazi University Ankara in Turkey. His research interests focus on experimental method of geography education, the teaching of geography in social studies education. 